\title{
Agro-Food Industry Byproducts into Value-Added Extruded Foods
}

\author{
Ilankovan Paraman*1, Kamran M. Sharif ${ }^{1}$, Susmoko Supriyadi ${ }^{1}$, Syed S.H. Rizvi ${ }^{1}$ \\ ${ }^{1}$ Department of Food Science, Cornell University, Stocking Hall, Ithaca, NY 14853, United \\ States
}

*Corresponding author (Current address). DuPont Nutrition \& Health, 4300 Duncan Avenue, St.

Louis, MO 63110. Phone: 314-659-3486.

Email: iparaman@gmail.com

Running Title: Supercritical Fluid Extrusion 


\begin{abstract}
Food industry co-products, fruit pomace and liquid whey, were converted into shelf-stable, puffed products by using low-shear, low-temperature supercritical fluid extrusion. Co-products were utilized as a source of dietary fiber, phytochemicals, and milk nutrients in extruded products. Liquid whey was concentrated and pumped directly into extruder barrel in lieu of water while processing cereal formulations fortified with finely ground fruit pomace. The resulting extruded products were very light in weight with $0.21-0.35 \mathrm{~g} / \mathrm{cm}^{3}$ density and contain $14 \mathrm{~g}$ dietary fiber, $93 \mathrm{mg}$ gallic acid equivalent polyphenols, and $652 \mathrm{mg}$ vitamin $\mathrm{C}$ equivalent antioxidants in $100 \mathrm{~g}$ products. The natural fruit color is retained in the final product, indicating the preservation of color pigments and the associated bioactive compounds. About $84 \%$ of the total phenolics and $74 \%$ of the antioxidants of apple pomace were preserved in the final extrudates. The utilization of the agro-industry waste streams offers effective preservation and utilization of the nutritionally attractive byproducts as a source of functional ingredients in extruded products while adding value to the industrial waste streams.
\end{abstract}

Keywords: Extrusion, value-added process, co-products, fruit pomace, supercritical fluid extrusion 


\section{Introduction}

Fruit pomace is a byproduct that remains after juice extraction from fruits and constitutes about $20-25 \%$ of the fresh fruit weight. It is treated as an industrial waste with very little or no economic value and is often used either as animal feed or returned to farms for composting. Since pomace contains large amount of water (66.4-78.2\%, wet basis) and fermentable sugars (3.6\%,wb), its direct disposal into soil creates environmental concerns due to uncontrolled fermentation and high chemical oxygen demand (300g COD/kg pomace) during its degradation.. Similarly, cheese whey is another co-product of cheese manufacture, about 9 pounds of whey is generated for each pound of cheese production. Cheese whey is an important source for high quality proteins, health promoting factors, and minerals (Walzem et al., 2002; Madureira et al., 2010). A considerable research emphasis has been directed towards better transforming byproducts generated from agro-food processing plants into various value-added products.

As a part of fruit, pomace has the potential to be transformed into various ingredients for food applications (Mahawar et al., 2012; Yu and Ahmedna, 2013). For instance, apple pomace, which consists of peel, core, and pulp, can be converted into various food and industrial ingredients such as citric acid (Mahawar et al., 2012; Hang et al. 1984), pectin (Schieber et al. 2003); alcohols (Madrera et al., 2013), enzymes (Dhillon et al.,2012), bio-adsorbents (Robinson et al., 2002) and biofuels (Vendruscolo et al. 2008). However, the economics of such undertakings is often found to be unattractive for commercialization of the developed processes. As a rich source of dietary fiber and phytochemicals, direct utilization of pomace in food applications offers an attractive opportunity to both processors and consumers. Although the direct use of fruit pomace in food applications has been studied for well over two decades (Wang 
and Thomas, 1989; Masoodi et al., 2002; Alavi et al., 2011), it has not reached commercialization due to its negative impacts on end-product sensory attributes.

Extrusion, as a continuous process with high versatility and productivity, offers a good avenue to incorporate fruit or vegetable pomace in ready-to-eat snacks and breakfast cereals. In addition to value addition to the byproducts, incorporating pomace can improve nutrient density of extruded products that are otherwise carbohydrate-rich, high glycemic products (Brennan et al., 2013). This will also help overcome nutrient shortfall in modern convenience food because fruit pomace is a good source of functional food compounds: dietary fibers $(60 \mathrm{~g} / 100 \mathrm{~g}$ apple pomace), polyphenols (350 mg/100g apple pomace) and a rich source of antioxidants.

Extrusion based food production is a multibillion dollar market and is a good channel to incorporate fruit based dietary fiber and phytochemicals into a number of products. Recent studies have clearly indicated the potential of incorporating various fruit and vegetable-based pomace in extruded products like apple pomace (Alavi et al., 2011; Karkle et al., 2002), grape pomace (Altan et al., 2008; Kumar et al., 2010), cranberry pomace (White et al., 2010), blue berry pomace (Khanal et al., 2009), tomato pomace (Altan et al., 2008), and carrot pomace (Altan et al., 2008) into various product matrices. However, the effect of pomace addition on extruded endproduct sensory and nutritional qualities was observed to be highly variable depending on extrusion conditions, pre and post-extrusion treatments, source of byproducts, etc. Conventional cooking extrusions used in previous studies are also based on high-temperature $\left(130-200^{\circ} \mathrm{C}\right)$ and high-shear (150-300 rpm) operations. Such high process requirements invariably lead to loss of sensory and nutritional qualities.

The present research utilizes supercritical fluid extrusion (SCFX), a modified process utilizing supercritical $\mathrm{CO}_{2}\left(\mathrm{SC}-\mathrm{CO}_{2}\right)$ as an expansion agent instead of steam. The process 
produces highly expanded, low-density products at process temperatures below $100^{\circ} \mathrm{C}$ and with low shear conditions (Rizvi and Mulvaney, 1992; Rizvi et al., 1995). Therefore, heat- and shearsensitive nutrients and bioactives can be effectively incorporated to produce nutrient enriched products without much loss (Alavi and Rizvi, 2002; Paraman et al., 2012). Such mild operating requirements are very advantageous when processing fruits, vegetables, and their byproducts, along with whey as a replacement for water which is required during extrusion processing. The objectives of this study were to develop novel extrusion protocols to directly incorporating fruit/dairy byproducts into shelf-stable, puffed, extruded products and evaluate changes in their quality due to processing.

\section{Materials and methods}

\subsection{Apple pomace and cheese whey preparation}

Apple pomace was obtained from the New York State Agricultural Experiment Station fruit processing pilot plants (Geneva, NY). Moisture content of wet apple pomace was $71 \%$ and $\mathrm{pH}$ was 4.8. Pomace was dried in a hot air oven at $50^{\circ} \mathrm{C}$ for about $48 \mathrm{~h}$ to a moisture content of 5-8\% (Oven model LR-27, ST333, LR Technologies, Los Angeles, CA). The dried pomace was ground into fine powder with a hammer mill using a 0.031 inch screen. Cheese whey was collected from cheddar cheese manufacturing operation at Cornell University (Ithaca, NY). It contained $5.6 \%$ total solids and the $\mathrm{pH}$ was 4.6 . The whey was concentrated to $\sim 20 \%$ total solids using a vacuum evaporator (Anhydro Laboratory Vacuum Evaporator) at $\sim 70^{\circ} \mathrm{C}$. The $\mathrm{pH}$ of the concentrated whey was 4.2. 


\subsection{Feed formulation}

Extrusion formulations consisting of fruit pomace and other required dry ingredients as shown in Table 1 were mixed for 9 minutes in a $0.14 \mathrm{~m}^{3}$ ribbon blender (Littleford Day Inc., Florence, KY, USA) to ensure uniform mixing. Preliminary experiments were conducted to determine the appropriate amounts of apple pomace (22 and 28\%). Pre-gelatinized corn starch obtained from Tate \& Lyle Ingredients (Decatur, IL, USA). Lecithin and distilled monoglyceride were provided by Danisco Ingredients (Kansas, MO).

\subsection{Supercritical fluid extrusion}

The dry-blended formulations were extruded in a pilot-scale Wenger TX-52 Magnum corotating twin screw extruder (Wenger Manufacturing, Sabetha, KS, USA) with a length to diameter ratio (L/D) of 28.5:1 (Rizvi et al., 1995). The extruder was operated at a feed rate of $35 \mathrm{~kg} / \mathrm{h}$ and screw speed of 100-120 rpm. Barrel temperature in all 5 barrel zones were maintained at $\sim 25^{\circ} \mathrm{C}$ by circulating chilled brine $\left(-10^{\circ} \mathrm{C}\right)$ through barrel jackets. The concentrated whey was directly pumped into the extruder barrel while processing fruit pomace in extruder at a flow rate of $27.5-32.0 \%$ of the dry-feed flow rate, which yielded $21-24 \%$ moisture content and $5.6 \mathrm{wt} . \%$ whey solids in extrudate. A diagram of the screw profile along with extrusion parameters used is shown in Fig. 1. The extruder parameters and operating conditions are summarized in Table 2 .

A pilot scale supercritical fluid system was used to generate $\mathrm{SC}-\mathrm{CO}_{2}$ and inject at a constant flow rate $(7.6 \times 10-5 \mathrm{~kg} / \mathrm{s})$ into the barrel through four valves located at $\mathrm{L} / \mathrm{D}$ of 24 . The $\mathrm{SC}-\mathrm{CO}_{2}$ was injected at $1100 \mathrm{psi}(7.58 \mathrm{MPa})$ to maintain a continuous flow of $\mathrm{SC}-\mathrm{CO}_{2}$ into the product 
melt (Rizvi et al., 1995). A flow restrictor was used to maintain the die pressure at $\sim 10 \mathrm{MPa}$ (1500 psi). The residence time inside the extruder is about 130 seconds for the screw speed (100 rpm) used in this study. The product melt was forced through one die insert of $4.2 \mathrm{~mm}$ diameter and cut by a 2-bladed knife rotating at $900 \mathrm{rpm}$ to obtain ball-shaped products. The product temperature at the die-exit was $\sim 80-90^{\circ} \mathrm{C}$. The final products were dried at $90^{\circ} \mathrm{C}$ to $\sim 5-8 \%$ moisture content in forced air oven (LR-27, ST333, LR Technologies, Los Angeles, CA) . Specific mechanical energy (SME) input into the dough was calculated from the following equation:

$$
S M E=37.3\left(\frac{\% \text { Extruder load }}{100}\right)\left(\frac{\text { Extruder screw speed }}{306}\right)\left(\frac{3600}{\text { Extruder feed rate }}\right)
$$

where extruder screw speed is in rpm $(100 \mathrm{rpm}), 306 \mathrm{rpm}$ is the maximum extruder screw speed, $37.3 \mathrm{~kW}$ is the power input and the extruder feed rate is in $\mathrm{kg} / \mathrm{h}(35 \mathrm{~kg} / \mathrm{h})$.

\subsection{Product characterization}

Piece density of extrudates was determined by sand displacement method; piece density was defined as the ratio of the sample mass of the sample to its volume to include internal pores but exclude the void or space between the extrudates. Bulk density is defined as the mass of particles divided by the volume they occupy that includes internal pores plus the space between extrudates and was measured by filling a container of known volume with the product. The procedure was repeated five times for each set of samples. Expansion ratio was calculated by dividing cross sectional area of the extrudate by the cross-sectional area of die opening. An average diameter of 10 samples was used to determine the expansion ratio of each set of samples. 
Textural properties of pomace extrudate were measured by using a TA-XT2 texture analyzer Texture Exponent 32 software (Micro Systems, Godalming, UK). Extrudate was equilibrated in a humidity chamber containing saturated calcium chloride (28\% RH) for $48 \mathrm{~h}$ before texture analysis. The test was performed by compressing the samples to $80 \%$ of their original diameter using a $35 \mathrm{~mm}$ compression plate at test speed of $2 \mathrm{~mm} / \mathrm{s}$. Peak force (N), number of peaks, and initial gradient $(\mathrm{N} / \mathrm{mm})$ of the force-deformation curve were recorded and used to calculate hardness, crispiness, and compression modulus of the products, respectively. An average of 12 samples was used to determine these properties.

Internal microstructure of pomace extrudates were observed by LEICA 440 scanning electron microscope. Sample was cut into thin slices, mounted on aluminum stubs with double- sided adhesive tape, coated with gold-palladium, and examined at an intensity of $5 \mathrm{kV}$.

Antioxidant capacities and phenolic contents of apple pomace and extrudates were evaluated using the methods described by Prior et al., 2005. Moisture content of the dry-blend and dried extrudates was measured by using oven drying method at $130^{\circ} \mathrm{C}$ for 2 hours (AACC 44-31, 2000). Extrusion trials were conducted in duplicate. Data were analyzed by analysis of variance using JMP 9.0.1 statistical software (SAS Institute Inc. 2010). Tukey-Kramer HSD test was used to determine the least significant differences (LSD) at 5\% significance level.

\section{Results and discussion}

\subsection{Nutrient retention}

Dried apple pomace and its extruded counterparts are shown in Fig. $2 \& 3$. As noted, the natural color of pomace was preserved during extrusion process, indicating that the conditions 
used during the SCFX process preserved the product color and associated bioactive nutrients in the final products. Final product contained $93 \mathrm{mg}$ gallic acid equivalent phenolics, and $652 \mathrm{mg}$ vitamin $\mathrm{C}$ equivalent antioxidants in $100 \mathrm{~g}$ (Fig. 4). The process thus retained $84 \%$ of the total phenolics and $74 \%$ of total antioxidants present in the original apple pomace.

Color pigments and bioactive compounds are typically sensitive to high heat and shear used in conventional steam extrusion (Brennan et al., 2011). A wide range of bioactive compound loss (46-65\%) has been reported depending on the severity of conventional steam extrusion (Kumar et al., 2010; Khanal et al., 2009; Camire et al., 2007). For instance, only 35\% of the total anthocyanin present in cranberry pomace were retained at high barrel temperature $\left(190^{\circ} \mathrm{C}\right)$ and screw speed $(200 \mathrm{rpm})$; the retention was increased to $54 \%$ when the barrel temperature was reduced to $150^{\circ} \mathrm{C}$ (Khanal et al., 2009), however, the study did not indicate the physical characteristics or textural qualities of final products. Camire et al. (2007) reported a $10-90 \%$ loss of anthocyanin for extrusion cooking of various fruit powders. The losses are mainly due to high temperature $\left(170^{\circ} \mathrm{C}\right)$ and high shear $(175 \mathrm{rpm})$ used in the extrusion. Mainly, phenolic acids are decarboxylated and condensed into tannins at high temperature processing (Brennan et al., 2011) although the phytochemical are stable in apple pomace due to its high content of complex polysaccharides that provide protective effect upon heating (Lavelli and Kerr 2012). Several extrusion variables impact the nutrient retention of final extruded products and most critical of them are barrel temperature, feed moisture, shear, and energy input (Riaz et al., 2009). Compared to the phenolic losses reported in literature, the losses were significantly lower in this current study due to low-temperature, low-shear conditions used in the SCFX process. 


\subsection{Nutrient enrichment}

Nutrient contents of the apple pomace extrudate, apple pomace-cheese whey extrudate, and protein fortified apple pomace extrudates are given in Table 4 . By incorporating $22 \%$ pomace, the total dietary fiber content of extruded products increased from 0.8 to $14 \mathrm{~g} / 100 \mathrm{~g}$ product. Furthermore, apple pomace has good amounts of soluble dietary fiber (8-20 g/100 g pomace), comparable to whole grain oat that contains the highest amounts of soluble fiber (6-8 g/ $100 \mathrm{~g})$ among all cereal grains (Manthey et al., 1999). In addition to dietary fiber, the pomace incorporated products contained good amount of phenolics ( $93 \mathrm{mg} / 100 \mathrm{~g}$ product), whereas the control product had negligible amounts of dietary fiber and phenolics. Consequently, compared to cereal grains, pomace incorporated extrudates may be considered as functional cereals with balanced nutrients derived from inexpensive, edible byproducts.

By incorporating micronutrients (peptides, sugars, vitamins, \& minerals) present in cheese whey, the overall quality of extruded products is further improved. The addition of cheese whey improved the mineral and soluble sugar contents of the final extruded products from 0.6 to $0.9 \%$ and from 0.5 to $4.4 \%$, respectively. The rich amount of minerals in whey can help reduce the need of added salt in extruded products. Given the low amount of cheese whey ( $5.1 \%$ cheese whey on dry solids basis) that was incorporated into extruded products, major nutrients such as protein in the final extrudates were not significantly altered. Furthermore, addition of cheese whey into extruded products is not likely to be attractive due to its high content of lactose, $76 \%$ of the total cheese whey solids.

As an example of utilizing apple pomace in ready-to-eat products, protein fortified apple pomace puffs were prepared with a modified formulation containing $22 \%$ apple pomace, $12 \%$ soy protein and 7\% dried yoghurt powder, which further improved the nutritional profile of the 
protein fortified products compared to the control pomace-only extrudates. Protein content of the product increased from 1.5 to $12.1 \%$ and total dietary fiber content also improved from 14.2 to $16.5 \mathrm{~g} / 100$-g product compared to control the pomace extrudates (Table 4). Our previous study indicated that nutritional quality of proteins were well preserved when whey protein concentrate was extruded into whey crisps by SCFX even in the presence of $8 \%$ fructooligosaccharides (Paraman et al., 2013); 92\% of the total essential amino acids were retained after SCFX process.

As the modern diet is reported to be deficient in dietary fiber, the extruded products enriched in apple pomace offer an attractive route to address such deficiencies in a very cost effective manner. The fruit pomace fortified extrudates can be consumed as breakfast cereals, ready-to-eat snacks or converted into crisps for use as ingredients in various product applications such as nutrition bars, desert toppings, salads, baked products, etc. Utilizing food processing byproduct like pomace and whey as a source of nutrients in extrusion applications will help minimize their disposal problems and mitigate any environmental concerns.

\subsection{Textural properties}

The textural characteristics of pomace and cheese whey incorporated extrudates are given in Table 5. The $22 \%$ pomace incorporated puffed products made by SCFX showed characteristics of excellent low-temperature expanded products, with expansion ratio of 6.8 to 8.6. As a result, the products were very light in weight with piece density ranging from 0.21 to $0.35 \mathrm{~g} / \mathrm{cm} 3$ and bulk density from 0.14 to $0.27 \mathrm{~g} / \mathrm{cm} 3$. Typical commercial low-density puffed snacks prepared by conventional steam extrusion have a density in the range of $0.02-0.7$ $\mathrm{g} / \mathrm{cm} 3$ and the pomace-based extrudates fall well within this range, indicating the potential of 
incorporating a significant quantity of fruit pomace into ready-to-eat cereals without impairing their textural qualities.

Compared to starch-alone extrudates, in apple pomace (22\%) incorporated extrudates, the expansion decreased from 10.7 to 8.6 , and bulk density increased from 0.14 to $0.22 \mathrm{~g} / \mathrm{cm}^{3}$. The reduced expansion of the pomace products was due to reduced extensibility and gas holding capacity of the dough caused by insoluble fiber in pomace. Previous studies have reported that addition of pomace or fiber reduced radial expansion of starch based extrudates (Altan, et al., 2008; Karkle et al., 2012). However, Karkle et al. (2012) reported that although apple pomace decreased radial expansion, it did not decrease the overall volumetric expansion, which was due to increased longitudinal expansion assisted by alignment of fibers in the direction of extrusion. The volumetric expansion, as expected, decreased from 4.8 to $3.4 \mathrm{~cm}^{3} / \mathrm{g}$ with the addition of pomace due to corresponding increase in piece density (Table 5). As indicated in Table 2, the specific mechanical energy (SME) input for SCFX process ranged only from 125$188 \mathrm{~kJ} / \mathrm{kg}$ for pomace products, which was much lower than what is generally reported for conventional extrusion, 400-800 kJ/kg (Karkle et al., 2012). This is partly due to higher moisture in feed formulation that is used to reduce the viscous dissipation of mechanical energy into heat to keep the temperature below $100^{\circ} \mathrm{C}$ to avoid steam formation.

Apple pomace incorporation did not affect the hardness and crispiness of the products made by the SCFX process. This contradicted the typical inverse relationship between expansion ratio and hardness; a decrease in expansion generally increases the hardness of extrudate. The pomace extrudates might be more brittle compared to those of starch products due to insoluble fiber of pomace serving as weak points in the extruded matrix. Although thickness of the air cells of an extrudate largely determines the hardness of product, air cell 
density and cell size distribution also contribute to the mechanical properties of the extrudate (Agbisit et al., 2007). Besides, as shown in Table 3, the optimal expansion of starch-alone extrudate required higher moisture (35\%) in the feed compared to apple pomace-containing extrudates (22-24\%), which was due to high hydration capacity of pre-gelatinized starch compared to apple pomace-based formulations which had lower starch contents.

The apple pomace extrudate processed with cheese whey also showed good overall textural characteristics. The addition of cheese whey at $5.1 \%$ solid (dry weight basis) did not affect the textural qualities of extrudates. Onwulata et al. (1998) reported that addition of high amount of whey solids (25-50\%) decreased extrudate expansion and increased product hardness, which was due to high water binding properties of whey solids. The authors also reported darkened color of the extrudates due to Maillard browning, especially when using high shear process at $300 \mathrm{rpm}$ and $128^{\circ} \mathrm{C}$ melt temperature. Since the present study used cheese whey to provide only $\sim 5 \%$ whey solids, no differences in textural quality were observed. Besides, low-shear and low-temperature conditions used in SCFX process did not cause any color change, indicating the absence of browning reaction in final extrudates even though the feed formulation of both pomace and whey contained a considerable amount of soluble sugars.

\subsection{Internal morphology}

The micrographs presented in Fig. 5 confirmed that puffed pomace products made by SCFX process contained unique internal morphology with higher air-cell density compared to the control sample processed without $\mathrm{SC}-\mathrm{CO}_{2}$. The average diameter of the internal air cell of the control starch extrudate was $128 \pm 30 \mu \mathrm{m}$. When $22 \%$ apple pomace was incorporated, the air 
cell size increased to $176 \pm 57 \mu \mathrm{m}$, the number of opened/damaged cells increased, and number of air cell density decreased, resulting in less expanded and collapsed internal structure. All the SCFX processed expanded products have with unique internal microstructure (uniform air cell distribution, size, and density) compared to conventional steam extrusion; the air cells were small in size $(128-176 \mu \mathrm{m})$ and distributed uniformly throughout the products, which is due to less forceful, controlled puffing nature of SCFX. The unique internal cell structure of the extrudate was an indicative of improved textural and sensory attributes. On the other hand most typical puffed products generated by conventional steam expansion have large air cells (1-2 mm diameter) with less uniform internal micro-structure.

\section{Conclusion}

Supercritical fluid extrusion was used to process apple pomace and cheese whey into nutrient-enriched, shelf-stable puffed extruded products. The process utilized low-temperature ( $\sim 25^{\circ} \mathrm{C}$ barrel temperature, $\sim 90^{\circ} \mathrm{C}$ melt temperature), low-shear (100 rpm screw speed) conditions with $1 \% \mathrm{SC}-\mathrm{CO}_{2}$ as blowing agent. The resulting extrudates were very light in weight with $0.21-0.35 \mathrm{~g} / \mathrm{cm}^{3}$ density and contained $14 \mathrm{~g}$ dietary fiber, $93 \mathrm{mg}$ phenolics, and $652 \mathrm{mg}$ vitamin $\mathrm{C}$ equivalent antioxidants in $100 \mathrm{~g}$ products. The addition of cheese whey $(5.1 \%$ solids by dry weight) improved mineral content of the final products from 0.3 to $0.6 \%$ (w/w), but did not contribute to other major nutrients. The use of cheese whey in lieu of water did not affect the textural qualities of the final extrudates. Overall, the extrusion process produced low density puffed products enriched in dietary fiber and natural antioxidants while providing new opportunities to processors to sustainably transform their byproducts into value-added, edible products of utility and high commercial significance. 


\section{Acknowledgements}

We thank Prof. Chang Y. Lee for providing the phenolic and antioxidant analyses, Mr. Tom Gibson (New York State Agricultural Experiment Station, Geneva, NY) for providing apple pomace for this research, Mr. Sean Schell for his technical assistance during extrusion processing, and Wenger Manufacturing, Inc. (Sabetha, KS, USA) for providing the TX-52 magnum extruder used in this research.

Funding source: This work was supported by the USDA National Institute of Food and Agriculture, Hatch project NYC 2013-14-345. Any opinions, findings, conclusions, or recommendations expressed in this publication are those of the authors and do not necessarily reflect the view of the National Institute of Food and Agriculture (NIFA) or the United States Department of Agriculture(USDA)

\section{References}

AACC International, 2000. Approved Methods of the American Association of Cereal Chemists, 10th Ed. Methods 44-31. The Association: St. Paul, MN.

Agbisit, R., Alavi, S., Cheng, E.Z., Herald, T., Trater, A., 2007. Relationships between microstructure and mechanical properties of cellular cornstarch extrudates. Journal of Texture Studies, 38, 199-219.

Alavi, S., Karkle, E., Adhikari, K., Keller, L., 2011. Extrusion research for addressing the obesity challenge. Cereal foods world, 56, 56-60.

Alavi, S., Rizvi, S.S.H. 2009. Supercritical fluid extrusion - a novel method for producing microcellular structures in starch-based matrices. In Novel Food Processing - Effects on 
Rheological and Functional Properties, Eds. Ahmed, J., Ramaswamy, H.S., Kasapis, S., and Boye, J. Taylor and Francis. 2009.pp

Altan, A., McCarthy, K. L.,Maskan, M., 2008. Evaluation of snack foods from barley-tomato pomace blends by extrusion processing. J. Food Eng. 84, 231-242.

Brennan, C., Brennan, M., Derbyshire, E., Tiwari, B. K., 2011. Effects of extrusion on the polyphenols, vitamins and antioxidant activity of foods. Trends in Food Sci. \& Technol. 22, 570-575.

Brennan, M. A., Derbyshire, E., Tiwari, B. K., Brennan, C. S., 2013. Ready-to-eat snack products: the role of extrusion technology in developing consumer acceptable and nutritious snacks. International Journal of Food Science \& Technology, 48, 893-902.

Camire, M. E., Dougherty, M.P., Briggs, J.L., 2007. Functionality of fruit powders in extruded corn breakfast cereals. Food Chem. 101, 765-70.

Dhillon, G. S., Kaur, S., Brar, S. K., Verma, M., 2012. Potential of apple pomace as a solid substrate for fungal cellulase and hemicellulase bioproduction through solid-state fermentation. Industrial Crops and Products. 38, 6-13.

Hang, Y. D., Woodams, E. E.,1984. Apple pomace: A potential substrate for citric acid production by Aspergillus niger. Biotechnology Letters, 6(11), 763- 764.

Karkle, E. L., Alavi, S., Dogan, H., 2012. Cellular architecture and its relationship with mechanical properties in expanded extrudates containing apple pomace. Food research international, 46, 10-21. 
Khanal RC, Howard LR, Brownmiller C, Prior RL. 2009. Influence of extrusion processing on procyanidin composition and total anthocyanin contents of blueberry pomace. J. Food Sci. $74,52-58$.

Kumar, N., Sarkar, B. C., Sharma, H. K., 2010. Development and characterization of extruded product of carrot pomace, rice flour and pulse powder. African J. Food Sci. 4(11), 703-717.

Lavelli, V., Kerr, W., 2012. Apple pomace is a good matrix for phytochemical retention. J. Agric. Food Chem. 60, 5660-5666.

Madrera, R. R., Bedriñana, R. P., Hevia, A. G., Arce, M. B., Valles, B. S. 2013. Production of spirits from dry apple pomace and selected yeasts. Food and Bioproducts Processing, 91, 623-631.

Madureira, A.R., Tavares, T., Gomes, A.M., Pintado, M. E., Malcata, F.X., 2010. Invited review: Physiological properties of bioactive peptides obtained from whey proteins. J. Dairy Sci. 93, $437-455$.

Mahawar, M., Singh, A., Jalgaonkar, K., 2012. Utility of apple pomace as a substrate for various products: A review. Food and Bioproducts Processing, 90 (4), 597- 605.

Manthey, F.A. Hareland, G.A. Huseby, D.J., 1999. Soluble and insoluble dietary fiber content and composition in oat. Cereal Chem. 76, 417-420

Onwulata, C.I., Smith, P.W., Konstance, R.P., Holsinger, V.H., 1998. Physical properties of extruded products as affected by cheese whey. J. Food Sci. 63,814-818.

Paraman, I., Supriyadi, S., Wagner, M. E., Rizvi, S. S., 2013. Prebiotic fibre-incorporated whey protein crisps processed by supercritical fluid extrusion. International Journal of Food Science \& Technology, 48, 2193-2199 
Paraman, I., Wagner, M. E., Rizvi, S. H. 2012. Micronutrient and protein fortified whole grain puffed rice made by supercritical fluid extrusion. J. Agric. Food Chem. 60, 11188-11194.

Prior, R. L.; Xianli, W.; Schaich, K., 2005. Standardized methods for the determination of antioxidant capacity and phenolics in foods and dietary supplements. J. Agric. Food Chem. 53, $4290-4302$

Riaz, M. N., Asif, M., Ali, R., 2009. Stability of vitamins during extrusion. Critical Reviews in Food Science and Nutrition. 49, 361-368.

Rizvi, S.S. H., Mulvaney, S.J., 1992. Extrusion Processing with Supercritical Fluids. US Patent 5120559.

Rizvi, S.S.H., Mulvaney, S.J., Sokhey, A.S. 1995. The combined application of supercritical fluid and extrusion technology. Trends Food Sci. and Technol. 6, 232-240

Robinson, T. Chandran, B. Nigam, P., 2002. Removal of dyes from a synthetic textile dye effluent by biosorption on apple pomace and wheat straw. Water Research, 36 (2002), pp. 2824-2830.

Schieber, A.; Hilt, P.; Endree, H. U.; Rentschler, C.; Carle, R., 2003. A new process for the combined recovery of pectin and phenolic compounds from apple pomace. Innovative Food Sci. Emerging Technol. 4, 99- 107.

Vendruscolo, F., Albuquerque, P. M., Streit, F., Esposito, E., Ninow, J. L., 2008. Apple pomace: A versatile substrate for biotechnological applications. Critical Reviews in Biotechnology, $28,1-12$. 
Walzem, R. L., Dillard, C. J., German, J. B., 2002. Whey components: Millennia of evolution create functionalities for mammalian nutrition: What we know and what we may be overlooking. Critical Reviews in Food Science and Nutrition, 42, 353- 375.

Wang, H.J. Thomas R.L., 1989. Direct Use of Apple Pomace in Bakery Products. J. Food Sci. 54. 618-620.

White, B.L., Howard, L.R., Prior, R.L., 2010. Release of bound procyanidins from cranberry pomace by alkaline hydrolysis. J. Agric. Food Chem. 58, 7572-7579

Yu, J., Ahmedna, M., 2013. Functional components of grape pomace: their composition, biological properties and potential applications. International J. Food Sci. \& Technol. 48: $221-237$.

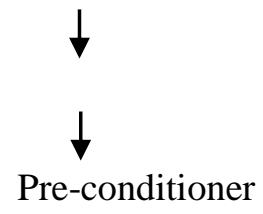




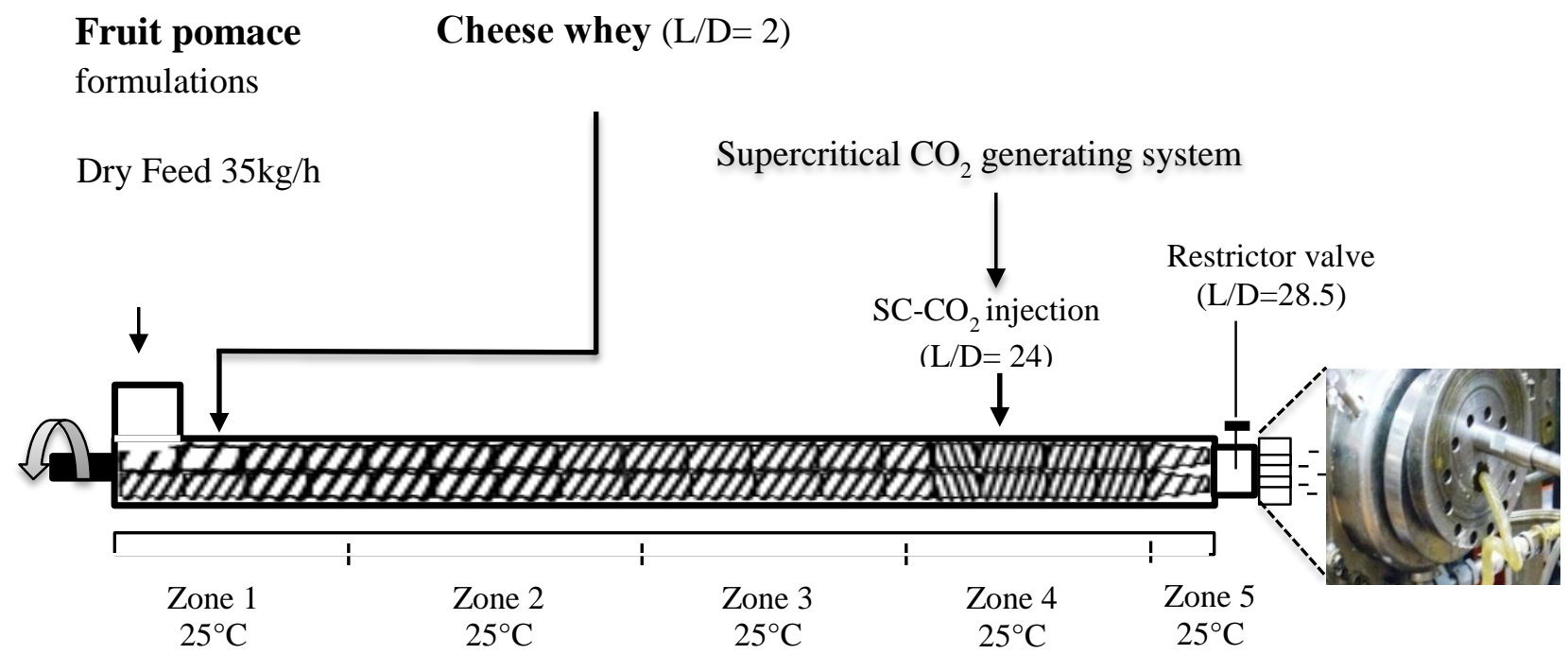

Fig. 1 - Schematic of supercritical fluid extrusion used to produce extrudates processed with fruit pomace and cheese whey. 

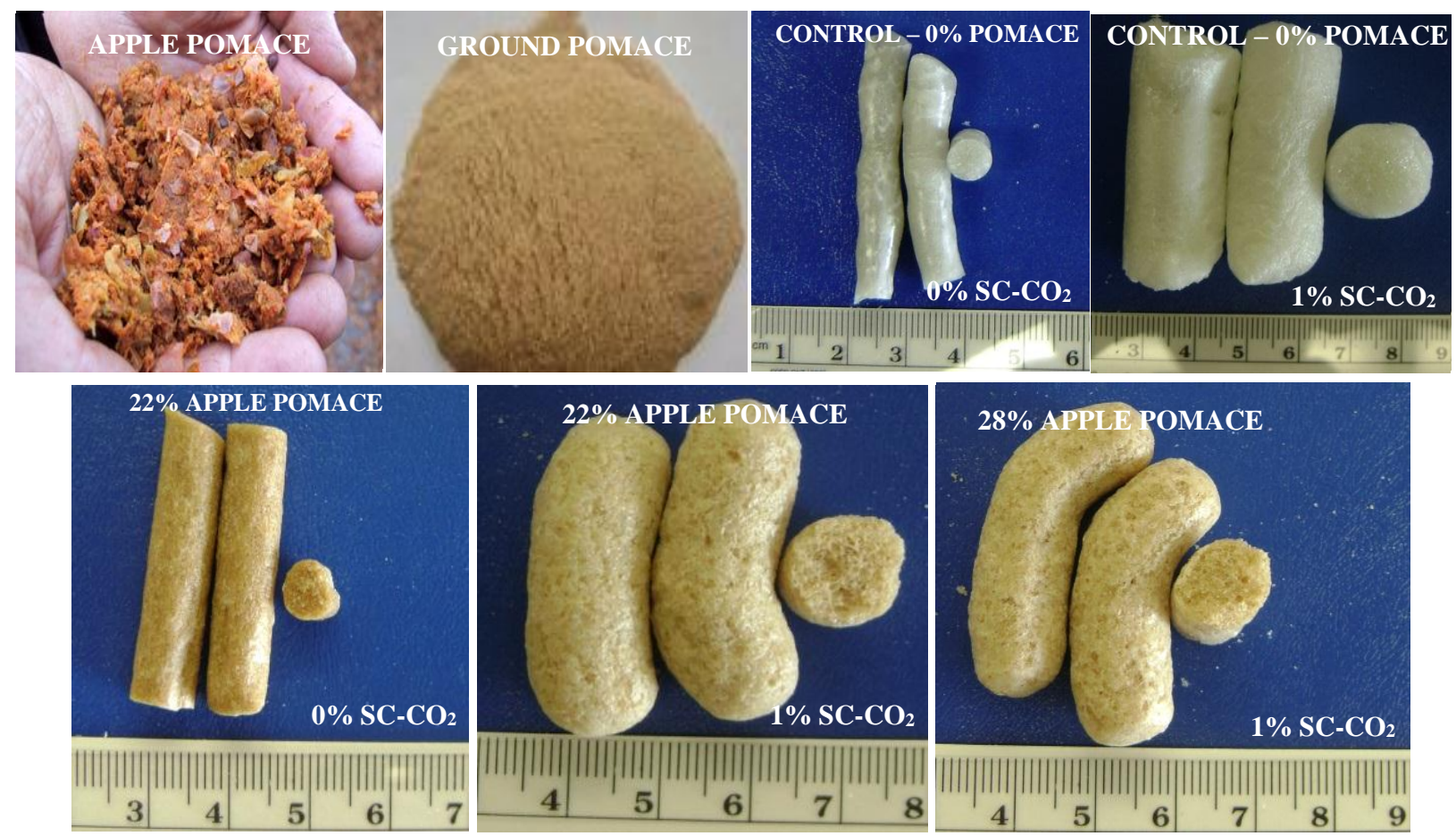

Fig. 2 - Photographs of apple pomace, dried and ground pomace, and extruded controls and apple pomace extrudates containing 22 and $28 \%$ pomace and $1 \mathrm{wt} . \%$ supercritical carbon dioxide. 


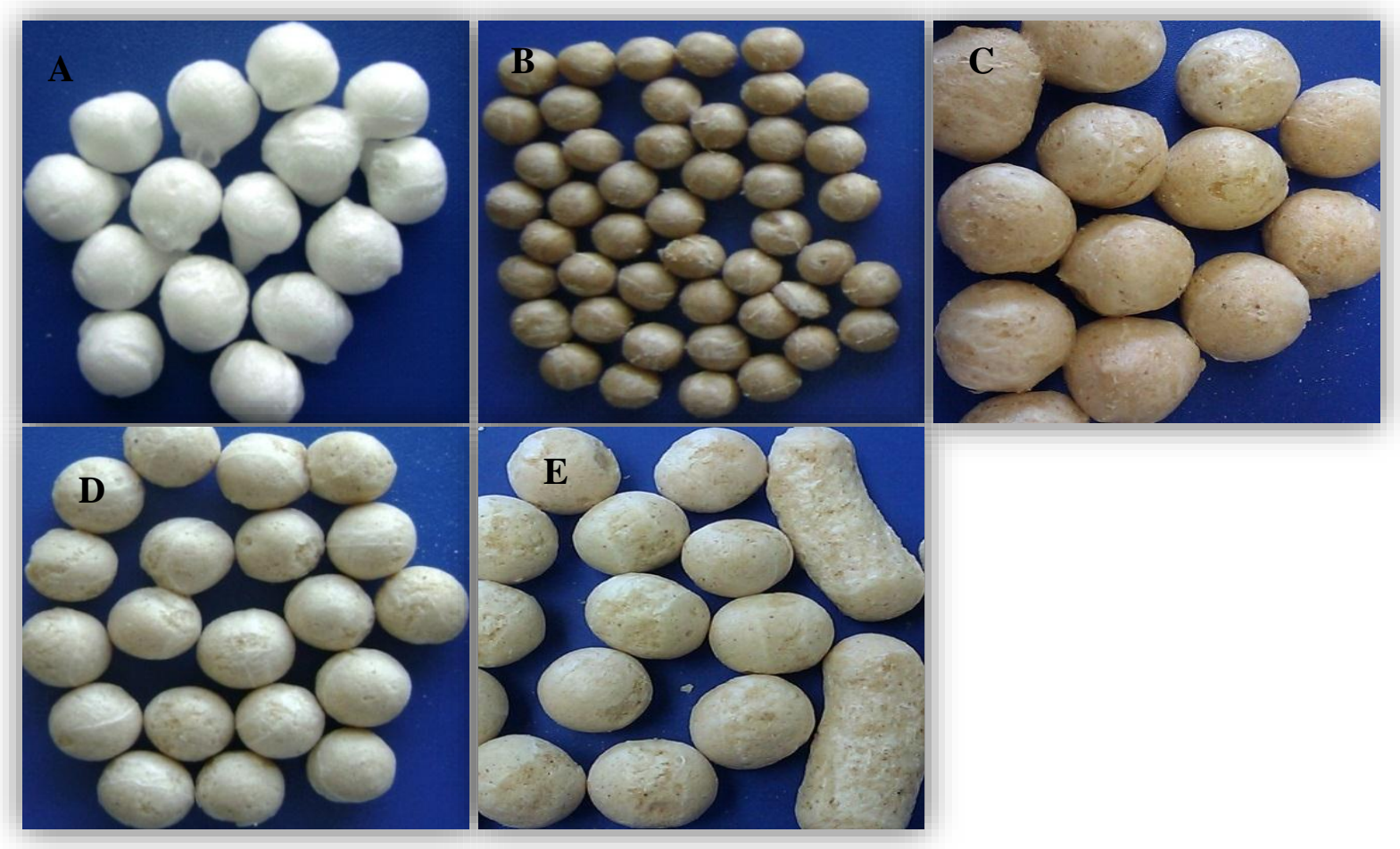

Fig. 3 - Apple pomace incorporated extrudates made by SCFX: (A) Starch extrudate with $1 \% \mathrm{SC}-\mathrm{CO}_{2}$; (B) $22 \%$ apple pomace extrudate without $\mathrm{SC}-\mathrm{CO}_{2} ;$ (C) $22 \%$ apple pomace extrudate with 1\% SC-CO2; (D) Apple pomace - cheese whey extrudate with 1\% SC-CO2; (E) Protein fortified apple pomace puffs made with $1 \% \mathrm{SC}-\mathrm{CO}_{2}$ 

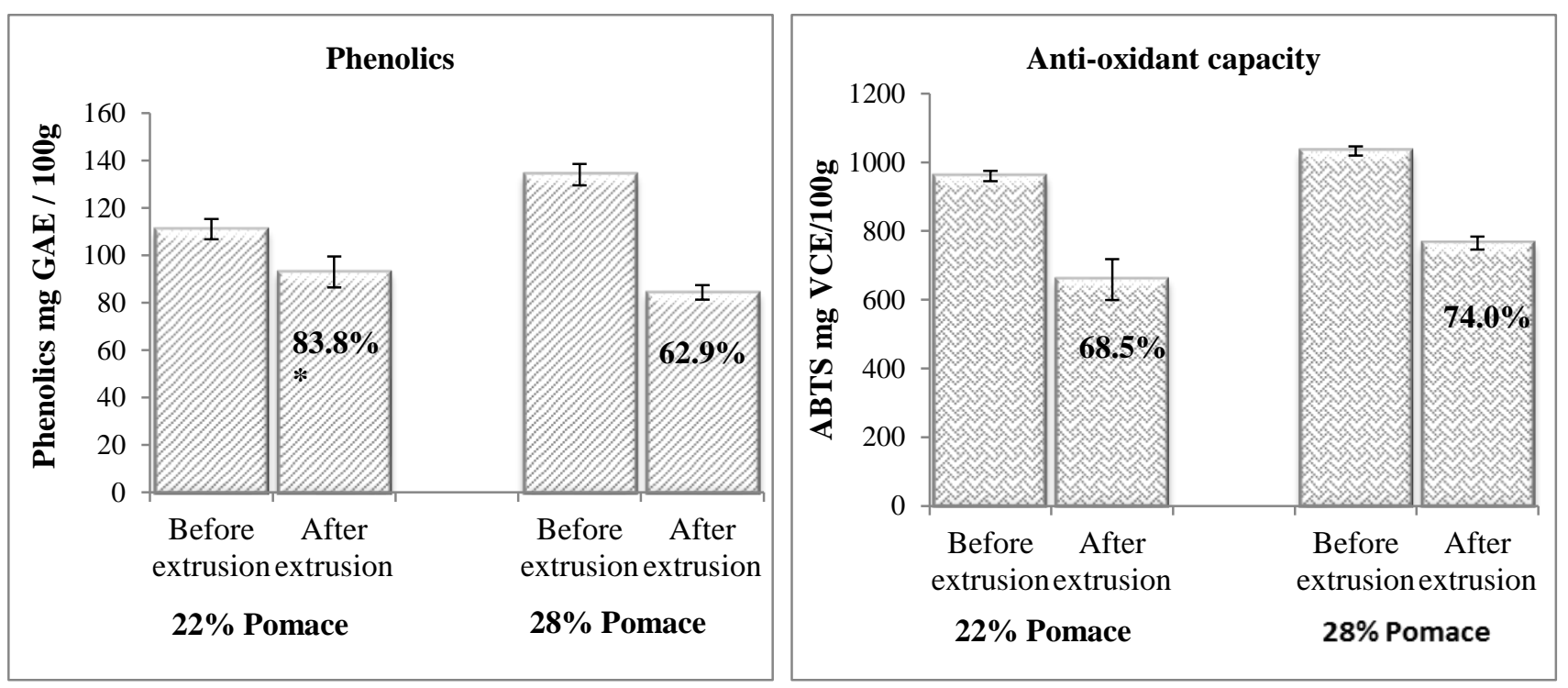

Fig. 4 - Retention of phenolics and anti-oxidant capacity of apple pomace extrudates before and after SCFX process. *The numbers on the bar indicates the percent retention of phenolics and antioxidants after the SCFX process and post-extrusion drying. 

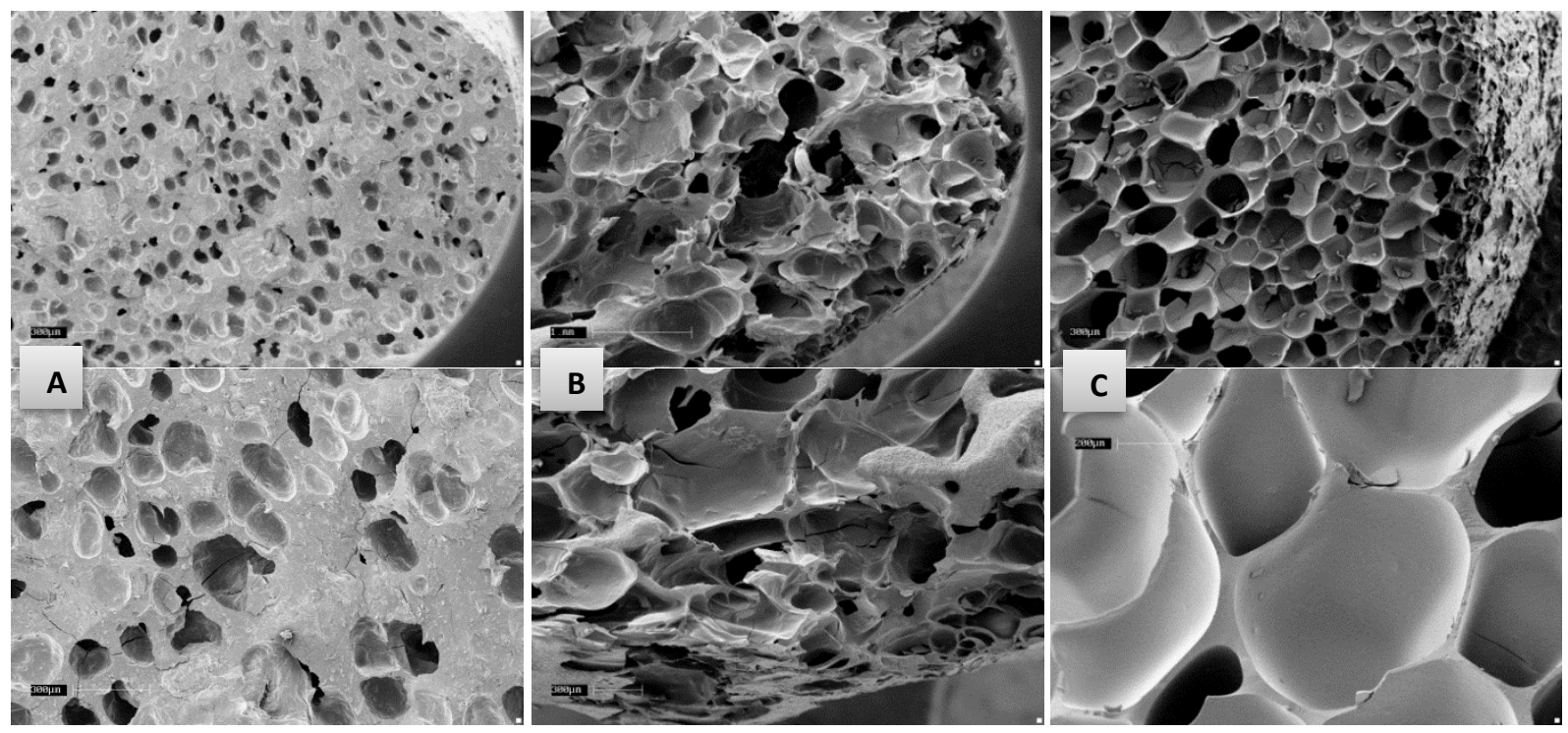

Fig. 5 - Scanning electron micrographs of extrudates made by SCFX: (A) apple pomace extrudate without $\mathrm{SC}-\mathrm{CO}_{2}$; (B) apple pomace extrudate with $1 \% \mathrm{SC}^{-\mathrm{CO}_{2}}$; (C) starch-alone extrudate with $1 \% \mathrm{SC}-\mathrm{CO}_{2}$. Micrographs in the upper and lower rows represent low $(\sim 25 x)$ and high ( $\sim 60 x)$ magnifications, respectively. 


\section{Table 1 - Feed formulations of apple pomace extrusion treatments}

Formulations

(i) Starch extrudate

(ii) Apple pomace extrudate

(iii)Apple pomace - cheese whey extrudate

(iv)Protein fortified apple pomace puffs

\section{Ingredient composition (\%, dry weight)}

$98 \%$ pre-gelatinized starch, $1 \%$ lecithin, and $1 \%$ distilled monoglycerides

$22 \%$ apple pomace, $76 \%$ pre-gelatinized starch, $1 \%$ lecithin, and $1 \%$ distilled monoglycerides

Same as (ii) and with added cheese whey (5.6\% dry wt.)

$22 \%$ apple pomace, $48 \%$ pre-gelatinized starch, $12 \%$ soy protein isolate, $7 \%$ dried yogurt powder, $7 \%$ brown Sugar, $1 \%$ lecithin, and $1 \%$ distilled monoglycerides, $.8 \%$ vanilla extract, $.5 \%$ apple flavor, $.6 \%$ salt, $.3 \%$ cinnamon, $.4 \%$ citric acid, $.2 \%$ nutmeg 
Table 2 - Supercritical fluid extrusion conditions and parameters for starch and apple pomace extrudates

\begin{tabular}{|c|c|c|c|c|}
\hline \multirow[b]{2}{*}{ Process parameters } & \multicolumn{4}{|c|}{ Process conditions } \\
\hline & $\begin{array}{l}\text { Starch } \\
\text { extrudate }\end{array}$ & $\begin{array}{l}\text { Apple pomace } \\
\text { extrudate }\end{array}$ & $\begin{array}{l}\text { Apple pomace - } \\
\text { cheese whey } \\
\text { extrudate }\end{array}$ & $\begin{array}{c}\text { Protein } \\
\text { fortified apple } \\
\text { pomace puffs }\end{array}$ \\
\hline Feed rate $(\mathrm{kg} / \mathrm{h})$ & 35 & 35 & 35 & 35 \\
\hline Extruder motor load (\%) & 12 & 10 & 13 & 15 \\
\hline Extruder screw speed (rpm) & 100 & 100 & 100 & 100 \\
\hline Water flow (\% Feed) & 35 & 24 & -- & 22 \\
\hline Cheese whey flow (\% Feed) & -- & -- & 26.4 & -- \\
\hline Barrel temperature $\left({ }^{\circ} \mathrm{C}\right)$ & $19-27$ & $21-26$ & $23-33$ & $24-30$ \\
\hline Die pressure (MPa) & 11.7 & 11.7 & 11.7 & 11.7 \\
\hline $\mathrm{SC}-\mathrm{CO}_{2}$ injection rate $(\mathrm{kg} / \mathrm{s})$ & $7.6 \times 10^{-5}$ & $7.6 \times 10^{-5}$ & $7.6 \times 10^{-5}$ & $7.6 \times 10^{-5}$ \\
\hline $\begin{array}{l}\mathrm{SC}-\mathrm{CO}_{2} \text { injection pressure } \\
(\mathrm{MPa})\end{array}$ & 7.58 & 7.58 & 7.58 & 7.58 \\
\hline Melt temperature at die $\left({ }^{\circ} \mathrm{C}\right)$ & 82 & 86 & 93 & 88 \\
\hline $\begin{array}{l}\text { Specific mechanical energy } \\
(\mathrm{kJ} / \mathrm{kg})\end{array}$ & 150.5 & 125.4 & 163.0 & 188.1 \\
\hline
\end{tabular}


Table 3 - Proximate composition of apple pomace ${ }^{a}$

\begin{tabular}{lc}
\hline Composition & $\begin{array}{c}\%(\mathrm{~g} / 100 \mathrm{~g}, \\
\text { dry basis })\end{array}$ \\
\hline Total dietary fiber $(\%)$ & 83.3 \\
Insoluble dietary fiber $(\%)$ & 63.3 \\
Soluble dietary fiber $(\%)$ & 20.0 \\
Protein $(\%)$ & 6.4 \\
Fat $(\%)$ & 5.4 \\
Soluble sugars $(\%)$ & 2.3 \\
Minerals $(\%)$ & 1.4 \\
Condensed Tannins $(\%)$ & 4.2 \\
Phenolics $(\mathrm{g} \text { GAE/lOOg })^{b}$ & 0.4 \\
Antioxidants $(\mathrm{g} \text { VCE/lO0g })^{b}$ & 1.3 \\
\hline
\end{tabular}

${ }^{a}$ Adapted from Karkle et al $2012(15) ;{ }^{b}$ Experimental values. GAE=gallic acid equivalent, VCE= vitamin $\mathrm{C}$ equivalent 
Table 4 - Nutritional composition of control and apple pomace extrudates ${ }^{\text {a }}$

\begin{tabular}{|c|c|c|c|c|}
\hline Composition & $\begin{array}{c}\text { Starch } \\
\text { extrudate }\end{array}$ & $\begin{array}{c}\text { Apple } \\
\text { pomace } \\
\text { extrudate }^{\mathrm{b}}\end{array}$ & $\begin{array}{l}\text { Apple pomace } \\
\text { - liquid whey } \\
\text { extrudate }\end{array}$ & $\begin{array}{c}\text { Protein } \\
\text { fortified apple } \\
\text { pomace puffs }\end{array}$ \\
\hline Dietary fiber (g/100 g product) & $<1.0$ & 14.2 & 14.2 & 16.5 \\
\hline Protein $(\mathrm{g} / 100 \mathrm{~g}$ product $)$ & $<1.0$ & 1.5 & 2.4 & 12.1 \\
\hline Fat $(\mathrm{g} / 100 \mathrm{~g}$ product $)$ & $<1.0$ & 1.2 & 1.6 & 1.5 \\
\hline Carbohydrates (g/100 g product) & 98.0 & 77.4 & 81.3 & 54.2 \\
\hline Soluble sugars (g/100 g product) & $<1.0$ & 0.5 & 4.4 & 7.6 \\
\hline Minerals (g/100 g product) & $<1.0$ & 0.3 & 0.9 & 0.9 \\
\hline Phenolics (mg GAE/100g) ${ }^{b}$ & - & 93 & $\mathrm{nd}^{\mathrm{c}}$ & nd \\
\hline Antioxidants (g VCE/100g) b & - & 652 & nd & nd \\
\hline
\end{tabular}

${ }^{a}$ Calculated based on ingredient composition listed in Table 1 on dry weight basis. ${ }^{b}$ Experimental values. ${ }^{c}$ Not determined. 
Table 5 - Textural characteristics of extrudates and a commercial sample ${ }^{\text {a }}$

\begin{tabular}{lccccc}
\hline Physical characteristics & $\begin{array}{l}\text { Starch } \\
\text { extrudate }\end{array}$ & $\begin{array}{c}\text { Apple } \\
\text { pomace } \\
\text { extrudate }\end{array}$ & $\begin{array}{c}\text { Apple pomace } \\
\text { - cheese whey } \\
\text { extrudate }\end{array}$ & $\begin{array}{c}\text { Protein } \\
\text { fortified } \\
\text { apple } \\
\text { pomace puffs }\end{array}$ & $\begin{array}{c}\text { Commercial } \\
\mathrm{Jax}^{\mathrm{b}}\end{array}$ \\
\hline Piece density $\left(\mathrm{g} / \mathrm{cm}^{3}\right)$ & $0.21 \mathrm{bc}$ & $0.29 \mathrm{~b}$ & $0.27 \mathrm{~b}$ & $0.35 \mathrm{a}$ & $0.17 \mathrm{c}$ \\
Bulk density $\left(\mathrm{g} / \mathrm{cm}^{3}\right)$ & $0.14 \mathrm{c}$ & $0.22 \mathrm{~b}$ & $0.24 \mathrm{~b}$ & $0.27 \mathrm{a}$ & $0.12 \mathrm{c}$ \\
$\begin{array}{l}\text { Expansion ratio } \\
\text { Specific volume }\left(\mathrm{cm}^{3} / \mathrm{g}\right)\end{array}$ & $4.8 \mathrm{bc}$ & $3.4 \mathrm{c}$ & $3.7 \mathrm{c}$ & $2.9 \mathrm{~d}$ & $5.9 \mathrm{a}$ \\
Hardness (N) & $22.1 \mathrm{ab}$ & $20.8 \mathrm{~b}$ & $25.2 \mathrm{ab}$ & $28.0 \mathrm{a}$ & $12.2 \mathrm{~b}$ \\
Crispiness (No. of peaks) & $18.3 \mathrm{~b}$ & $17.5 \mathrm{~b}$ & $15.8 \mathrm{bc}$ & $14.1 \mathrm{c}$ & $25.2 \mathrm{a}$ \\
$\begin{array}{l}\text { Compressive modulus } \\
\text { (N/mm) }\end{array}$ & $9.4 \mathrm{c}$ & $16.8 \mathrm{a}$ & $9.3 \mathrm{c}$ & $13.1 \mathrm{~b}$ & $13.8 \mathrm{~b}$ \\
\hline
\end{tabular}

${ }^{a}$ Means in the same row followed by the same letter are not significantly different $(p<0.05)$. Feed formulations of the extrudates are listed in Table 1.

${ }^{\mathrm{d}}$ Bachman Cheese Flavored Corn Snacks, Crunchy Jax Twists 